\title{
STABILITAS SENYAWA FENOLIK DALAM EKSTRAK DAN NANOKAPSUL KELOPAK BUNGA ROSELLA PADA BERBAGAI VARIASI PH, SUHU DAN WAKTU
}

\author{
Ike Sitoresmi M Purbowati ${ }^{1 *}$, Khaswar Syamsu ${ }^{2}$, Endang Warsiki ${ }^{2}$, Herastuti Sri $^{1}$ \\ ${ }^{1}$ Jurusan Teknologi Pertanian, Fakultas Pertanian, Universitas Jenderal Soedirman, \\ ${ }^{2}$ Jurusan Teknologi Industri Pertanian, Fakultas Teknologi Pertanian \\ Korespondensi : Jalan Dr. Suparno, Karangwangkal, Purwokerto 53123, Indonesia, email : \\ Ikesitoresmi@yahoo.co.id
}

\begin{abstract}
The extract which is still in liquid form, has several weaknesses, such as unstable in enviroment changes, low flexibility uses and trouble in material handling and transportation. For these reasons, nanoencapsulation technique using $\beta$-siklodextrin as matrix agent is an alternative way. The aims of this research were characterization of total phenols, antioxidant activity of nanoencapsulation and the stability of the extract as well as nanocapsules against the changes of $\mathrm{pHs}$, temperatures and boiling times. Nanocapsules of roselle extract was containing phenol 4,53+0,26 $\mathrm{mg} / \mathrm{g}$, anthocyanin 2,99+0,18 $\mathrm{mg} / \mathrm{g}$, vitamin C 2,77+0,04 $\mathrm{mg} / \mathrm{g}$ and water moisturizer 5,16 +0,03\%, antioxidant activity 49\%. Nanocapsules more resistence against the enviroment changes than the extract itself. The stability test against the enviroment changes, the nanocapsules form more stable than the extract. Showed with the slope of linier regression of nanocapsules form for phenols and antioxidant activity, respectively were: 0,111; 1,307 lower than the extract : 2,825; 7,634. Nanocapsules more resistence against temperature and boiling time than the extract itself. The stability test against temperature and boiling time, the nanocapsules form more stable than the extract. Showed with the slope of linier regression of nanocapsules for phenols and antioxidant activity respectively were: 1,3315; 0,3162 lower than the extract : 1,5864; 0,5389
\end{abstract}

Keywords: roselle, antioxidant, phenols, stability

\section{PENDAHULUAN}

Perkembangan industri pengolahan pangan berdampak pada peningkatan bahan tambahan makanan sintetis seperti pewarna, dan pengawet yang dirasakan tidak aman untuk kesehatan dalam jangka panjang. Disisi lain kesadaran masyarakat untuk mengganti penggunaan bahan sintetis kimia dengan bahan alami pada industrialisasi makanan semakin tinggi. Hal tersebut menjadi peluang bagi bahan tambahanan makanan alami terutama yang berasal dari tanaman.

Salah satu alternatif bahan alami tersebut adalah kelopak bunga rosella. Agar lebih fleksibel dalam pemanfaatannya, bahan bioaktif dalam kelopak bunga rosella diekstrak dari bahan dasar. Metode ekstraksi berbantu gelombang mikro terbukti efisien dalam mengekstrak senyawa-senyawa fenolik dari kelopak bunga rosella dibandingkan metode pemanasan konvensional. Purbowati
(2014) menyatakan bahwa ekstrak rosella hasil dari optimasi metode ekstraksi berbantu gelombang mikro dilakukan pada 250 Watt, konsentrasi etanol 78,36 selama 4,91 menit. Ekstrak rosella yang dihasilkan, memiliki kandungan senyawa bioaktif fenolik, antosianin dan vitamin $\mathrm{C}$ berturut turut : 23.77 $\pm 0.25 ; 14.80 \pm 0.08 ; 10.74 \pm 0,14 \mathrm{mg} / \mathrm{g}$ dan aktivitas antioksidan.

Namun demikian, ekstrak rosella yang masih dalam bentuk cair memiliki beberapa kelemahan, yaitu tidak tahan terhadap perubahan kondisi lingkungan, pemanfaatan yang terbatas dan kesulitan dalam masalah transportasi bahan. Untuk itu diperlukan alternatif bentuk ekstrak rosella, yang mampu mengatasi permasalahan ini. Salah satu cara yang dapat digunakan untuk melindungi keaktifan bahan dalam ekstrak rosella adalah melalui teknologi nanoenkapsulasi, yang merupakan teknik menyalut bahan inti dengan tujuan melindungi 
bahan inti dari pengaruh eksternal pada ukuran nano.

Aplikasi nanoteknologi untuk pangan menunjukkan kecenderungan yang terus meningkat. Teknologi ini menawarkan keunggulan dalam meningkatkan bioavaibilitas bahan aktif, pengendalian pelepasan bahan aktif serta memperbaiki sifat sensoris. Dalam ukuran nano $(50-500 \mathrm{~nm})$, partikel bahan aktif lebih mudah diabsorpsi dalam proses pengolahan pangan sehingga kemampuan melindungi produk pangan yang dihasilkan akan lebih baik. Absorpsi bahan aktif meningkat karena kelarutan partikel meningkat. Dalam ukuran nano, partikel juga memiliki waktu tinggal yang lebih panjang karena terjerap dalam sistem pangan. Bahan enkapsulan yang memenuhi kriteria tersebut terpilih $\beta$-siklodextrin (Wandrey et al., 2010; Naufalin dan Rukmini, 2013).

Bahan $\beta$-siklodextrin merupakan senyawa yang tersusun dari tujuh unit glukopiranosa yang terangkai dalam bentuk cincin. Molekulnya berbentuk kerucut terpancung dengan diameter dalam $0.58 \mathrm{~nm}$ dan diameter luar $0,78 \mathrm{~nm}$. Bagian dalamnya bersifat hidrofobik dan bagian luarnya bersifat hidrofilik. Senyawa ini dilaporkan tahan terhadap suhu hingga $200^{\circ} \mathrm{C}$ tanpa mengakibatkan bahan aktif yang terinklusi di dalamnya terlepas (Wandrey et al., 2010).

Yuliani et al. (2006) melaporkan bahwa enkapsulan yang menggunakan $\beta$ siklodextrin sebagai bahan enkapsulasinya memberikan perlindungan $d$-limonene lebih besar $(92,2 \%)$ dibandingkan sodium kaseinat $(67,5 \%)$. Hal ini disebabkan oleh $\beta$ siklodextrin mempunyai kestabilan terhadap panas yang baik. Shahidi dan Wasundara (1995) melaporkan bahwa $\beta$-siklodextrin lebih efektif sebagai bahan enkapsulan seal blubber oil dibandingkan sirup jagung padat dan maltodextrin, yaitu pada masa penyimpanan 49 hari penurunan asam lemak tidak jenuh adalah $10,17 \%$.

Di bidang pangan, antioksidan digunakan untuk melindungi lemak/minyak terhadap kerusakan oksidatif. Dalam kaitan dengan aplikasi ini, aktivitas antioksidan dipengaruhi oleh sistem pangan yang merupakan medium bagi antioksidan tersebut. Proses panas serta $\mathrm{pH}$ yang diterapkan pada pengolahan pangan mempengaruhi kestabilan aktivitas antioksidan.

Pengaruh bahan enkapsulan adalah spesifik, bergantung pada karakteristik inti yang dilindungi. Untuk itu perlu dikaji kesesuaian antara material inti dengan material penahan. Termasuk memastikan kestabilan bahan bioaktif rosella yang terkandung didalamnya.Tujuan dari penelitian ini adalah menentukan karakteristik nanoenkapsulan ekstrak rosella, serta menentukan stabilitas ekstrak dan nanoenkapsulan terhadap perubahan waktu, suhu dan $\mathrm{pH}$.

\section{METODE PENELITIAN}

\section{Bahan}

Bahan utama adalah kelopak bunga rosella yang didapat di pasar Beringharjo, Yogyakarta. Pelarut etanol (PA). Bahan enkapsulan $\beta$-siklodextrin.

\section{Alat}

Alat yang digunakan meliputi, Microwave elextrolux, rotary evaporator, deep freezer, freeze drier, timbangan dan stab mixer. Peralatan gelas yang diperlukan untuk ekstraksi, pembuatan bubuk nanoenkapsulan dan untuk analisis.

\section{Tahapan Penelitian}

\section{Ekstraksi}

Kelopak bunga rosella kering dihancurkan dengan meggunakan blender selama 1 menit dan diayak menggunakan saringan 60 mesh. Ekstraksi menggunakan konsentrasi pelarut etanol 78,36\%, daya gelombang mikro 250 Watt dan waktu ekstraksi 4,91 menit dengan rasio serbuk rosella dan pelarut 1:10 w/v (Purbowati, 2014). Campuran diradiasi dalam microwave dengan selang waktu tertentu (satu menit radiasi dan dua menit diistirahatkan ) untuk menjaga temperatur tidak naik melampaui titik didih (Li et al., 2009). Ekstrak rosella disaring menggunakan kertas Whatman 41 dan dipekatkan menggunakan vacuum rotary evaporator pada suhu $70^{\circ} \mathrm{C}$, dan tekanan 44 cmHg. Penentuan Vitamin C (AOAC, 2000), total kandungan antosianin (Fuleki dan 
Francis,1968). Pengujian fisik nanokapsul dilakukan dengan TEM

\section{Pembuatan nanoenkapsulasi}

Proses nanoenkapsulasi diawali dengan pembuatan larutan nanoenkapsulan. Bahan $\beta$ siklodextrin dicampurkan dengan air bebas ion dengan rasio total enkapsulan : air bebas ion; $1(\mathrm{~g}): 5(\mathrm{~mL})$ dan diaduk menggunakan magnetic stirrer selama 30 menit. Konsentrat rosella dimasukkan kedalam campuran dengan perbandingan ekstrak : bahan enkapsulan adalah 1: 20. Campuran kemudian dihomogenisasi pada suhu $40^{\circ} \mathrm{C}$ selama 30 menit. Pengecilan partikel menjadi nanopartikel dengan Tokebi $22.000 \mathrm{rpm}$ selama 5 menit, dan dikeringkan dengan freeze drier 16-18 jam. Setelah kering kemudian dihaluskan dengan mortar (Naufalin dan Rukmini, 2013).

\section{Preparasi sampel}

Sebelum dilakukan analisa, nanokapsul sebanyak $100 \mathrm{mg}$, ditambahkan 4 $\mathrm{mL}$ etanol $70 \%$. Kemudian dikocok dengan shaker menggunakan kecepatan 200 rpm selama 2 jam, selanjutnya campuran disentrifus selama 15 menit dengan kecepatan $1000 \mathrm{rpm}$. Supernatan yang diperoleh merupakan ekstrak untuk penetapan sampel nanokapsul.

\section{Pengujian pengaruh $\mathrm{pH}$ terhadap senyawa fenolik dan aktivitas antioksidan}

Ekstrak bunga rosella diuji pada berbagai $\mathrm{pH}$ yang diatur menggunakan larutan $\mathrm{HCl} 0,1 \mathrm{~N}$ dan $\mathrm{NaOH} 0,1 \mathrm{~N}$. Pengujian yang dilakukan meliputi total fenolik, total antosianin, dan aktivitas antioksidan. Pengujian stabilitas total phenol sampel terhadap perubahan $\mathrm{pH}(2,3,4,5,6,7$ dan 8$)$ dilakukan dengan cara mencampurkan $2 \mathrm{ml}$ ekstrak dengan $20 \mathrm{ml}$ buffer pada $\mathrm{pH}$ yang diperlukan. Campuran dibagi dalam tiga tabung reaksi, ditutup dan dilapisi dengan aluminium foil dan disimpan di tempat yang gelap pada suhu kamar. Perubahan kandungan total fenolik diukur dengan spektrometer pada $765 \mathrm{~nm}$.

\section{Pengujian pengaruh waktu dan suhu pemanasan terhadap senyawa fenolik dan aktivitas antioksidan}

Stabilitas senyawa fenolik terhadap suhu dilakukan pada suhu $60,70,80$ dan $90^{\circ} \mathrm{C}$. Sampel dilarutkan dengan buffer phosfat sitrat pada $\mathrm{pH} 2$ dan diukur total senyawa fenolik sebelum dipanaskan. Sebanyak $10 \mathrm{~mL}$ campuran diletakan pada tabung reaksi $20 \mathrm{~mL}$ dan dipanaskan dalam water bath selama 15, 30, dan 45, menit. Tabung reaksi segera didinginkan dan diukur kadar total fenolik sesudahnya dan aktivitas antioksidan.

\section{Total fenolik}

Total fenolik ditentukan menggunakan metode Folin-Ciocalteu Chew et al. (2009). Sebanyak 0,4 mL larutan sampel ditambahkan 1,5 mL reagen Folin-Ciocalteu $(10 \%, \mathrm{v} / \mathrm{v})$. Setelah diinkubasi 5 menit dicampur dengan 1,5 mL 7,5\% (w/v) larutan $\mathrm{Na}_{2} \mathrm{CO}_{3}$. Absorbansi sampel diukur pada 765 $\mathrm{nm}$ setelah 90 menit inkubasi pada suhu ruang dan gelap. Asam galat digunakan sebagai standar. Hasil yang didapat dinyatakan sebagai mg ekuivalen asam galat (GAE)/g bahan. Seluruh perlakuan diulang sebanyak 4 kali.

\section{Uji aktivitas antioksidan}

Pengujian aktivitas antioksidan dilakukan dengan metode Ferric Thiocyanate (Al-Hashimi, 2012). Sampel nanokapsul terlebih dahulu dipersiapkan mengikuti cara sebagai berikut: sebanyak $100 \mathrm{mg}$ nanoenkapsulan ditambah dengan $4 \mathrm{~mL}$ etanol 70\%. Kemudian dikocok dengan shaker menggunakan kecepatan $200 \mathrm{rpm}$ selama 2 jam, selanjutnya campuran disentrifugasi selama 15 menit dengan kecepatan $1.000 \mathrm{rpm}$. Supernatan yang diperoleh merupakan ekstrak untuk penetapan sampel.

Sebanyak 0,6 mL ekstrak dilarutkan dalam $0,12 \mathrm{~mL}$ etanol $98 \%$ dan $2,88 \mathrm{~mL}$ larutan $2,51 \%$ asam linoleat dalam etanol. Ditambahkan $9 \mathrm{~mL}$ buffer phosphate $40 \mathrm{mM}$ (pH 7). Campuran diinkubasi dalam gelap pada suhu $40^{\circ} \mathrm{C}$ selama 3 hari. Setelah inkubasi $0,1 \mathrm{~mL}$ larutan diambil dan ditambahkan 9,7 mL etanol 75\%;0,1 mL ammonium thiosianate $30 \%$ dan $0,1 \mathrm{~mL} 20$ $\mathrm{mM}$ Ferrous chloride dalam 3,5 $\mathrm{HCl}$. Absorbansi diukur pada $500 \mathrm{~nm}$ setelah inkubasi selama 3 menit. Tingkat oksidasi diukur dengan dengan menghitung rasio absorbansi terhadap blanko (tidak dengan sampel ekstrak). 


\section{HASIL DAN PEMBAHASAN}

\section{Karakteristik nanokapsul}

Nanoenkapsulasi bahan aktif rosella dengan bahan enkapsulan $\beta$ siklodextrin diharapkan mampu memberikan proteksi yang maksimal. Proses ini merupakan salah satu alternatif untuk menjaga stabilitas bahan aktif itu sendiri. Air merupakan komponen yang penting dalam bahan pangan karena akan mempengaruhi kenampakan, tekstur dan cita rasa. Kandungan air dalam bahan mempengaruhi ketahanannya terhadap serangan mikroba yang pada akhirnya menentukan bagi umur simpan. Pengeringan dilakukan dengan menggunakan freeze drier untuk menjaga kestabilan bahan aktif dari kerusakan akibat panas.

Hasil uji TEM yang dilakukan terlihat pada Gambar 1 menunjukkan ukuran nanokapsul yang dihasilkan berkisar 30-40 $\mathrm{nm}$. Dengan demikian bubuk enkapsulan ekstrak rosella ini layak disebut sebagai nanokapsul. Ukuran nanokapsul yang halus ini nampaknya berpengaruh pada prosentase bahan inti (ekstrak) yang terperangkap didalam bahan pengisi (filler). Hal ini ditampilkan pada Tabel 1.
Pada Tabel 1 terlihat bahwa bahan inti yang terperangkap dalam $20 \mathrm{~g}$ matriks hanya 90,6 mg dari 109,4 mg senyawa fenolik yang ditambahkan saat proses enkapsulasi, atau sekitar 93,25\%. Terdapat selisih bahan bioaktif yang ditambahkan dengan yang terjerap diduga karena terjadi kerusakan pada saat enkapsulasi, terutama karena oksidasi panas, oksigen, dan mekanis.

Gambar 2 menunjukkan senyawasenyawa bioaktif rosella masuk ke dalam lubang yang berada di dalam filler. Bahan $\beta$ siklodekstrin seperti yang diketahui memiliki permukaan luar yang hidrofilik dan permukaan dalam yang hidrofobik. Meski demikian, senyawa ini mampu menjerat dengan baik senyawa aktif kelopak bunga rosella di dalamnya. Hal ini dikarenakan penggunaan rpm yang tinggi pada saat nanoenkapsulasi seperti ilustrasi pada Gambar 2. Keuntungan dari kondisi ini adalah bahwa bahan inti tidak bereaksi dengan bahan pengisi, sehingga aktivitas bahan aktif di dalamnya sama baik dengan sebelum dinanoenkapsulasi jika proses enkapsulasi berjalan dengan baik.

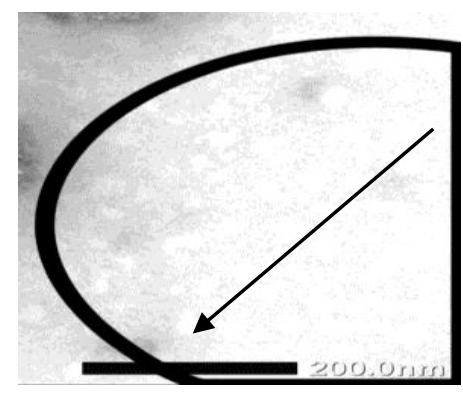

Gambar 1. Hasil uji TEM nanoenkapsulan rosella

Tabel 1. Persentase penyerapan senyawa bioaktif dalam nanokapsul

\begin{tabular}{llcl}
\hline & Nanokapsul $(\mathrm{mg})$ & Ekstrak $(\mathrm{mg})$ & \% Penjerapan \\
\hline Vitamin C & 55,4 & 59,41 & 93,25 \\
Fenolik & 90,6 & 109,4 & 82,81 \\
Antosianin & 59,8 & 69.2 & 86,41 \\
\hline
\end{tabular}

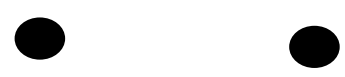




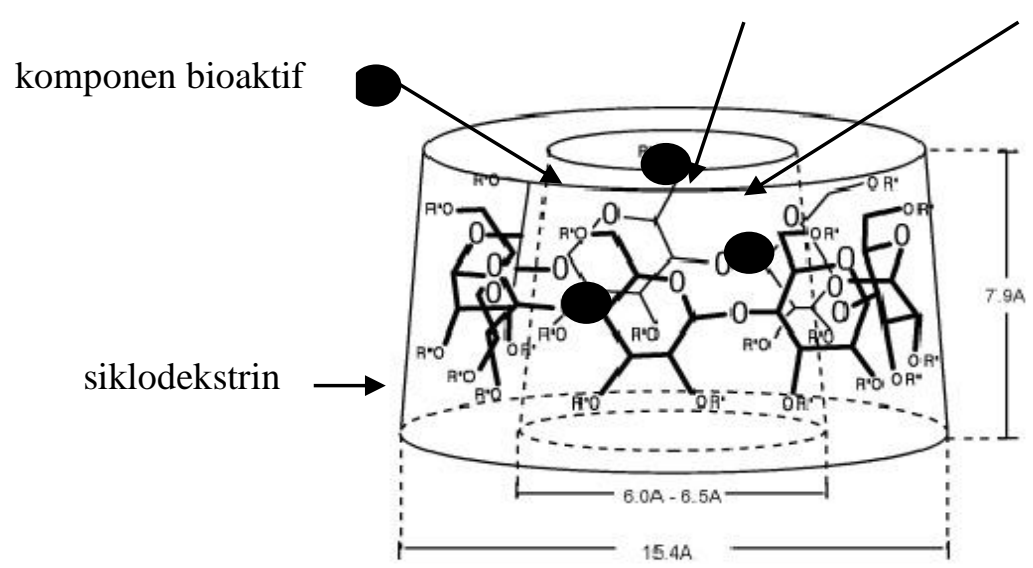

Gambar 2. Ilustrasi pengisian senyawa bioaktif rosella ke dalam siklodextrin (sumber.siklodextriner.com termodifikasi)

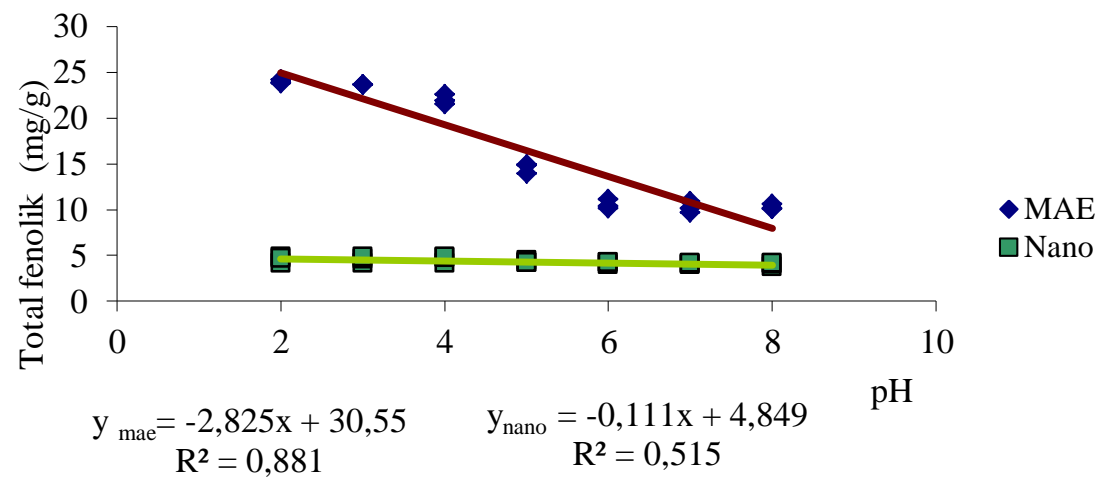

Gambar 3 Pengaruh variasi $\mathrm{pH}$ terhadap total fenolik

Pengaruh variasi pH terhadap senyawa fenolik, aktivitas antioksidan

Stabilitas senyawa fenolik dalam ekstrak rosella diuji pada kisaran $\mathrm{pH}$ 2-8. Terlihat pada Gambar 3 dibawah ini, semakin tinggi $\mathrm{pH}$, untuk ekstrak kelopak bunga rosella, semakin turun total fenolik yang diperoleh. Hal ini karena sebagian besar kandungan fenolik dalam rosella, sebagian besar ditentukan oleh sifat antosianin didalamnya. Menurut Selim et al. (2005) pada $\mathrm{pH}$ 2-4 antosianin rosella masih memiliki retensi yang cukup tinggi. Pada $\mathrm{pH}$ 6-8 warna ekstrak cenderung kebiruan

Kandungan fenolik dalam ekstrak kelopak bunga rosella relatif stabil pada $\mathrm{pH} 2-$ 4 kemudian menurun hingga $\mathrm{pH} 6$ seperti terlihat dari Gambar 3. Hal ini ditandai dengan perubahan warna merah gelap menjadi merah pucat hingga mendekati tanpa warna. Sebaliknya bentuk nanokapsul memberikan stabilitas fenolik yang lebih baik dibandingkan dalam bentuk ekstrak. Terlihat dari slope persamaan regresi yaitu 0,111 lebih kecil dibandingkan slope persamaan regresi dalam bentuk ekstrak, yaitu 2,825. Tanda negatif menunjukkan bahwa terjadi penurunan terhadap kandungan fenolik baik dalam bentuk ekstrak maupun nanoenkapsulan.

Hal ini juga mengindikasikan setiap kenaikan satu satuan $\mathrm{pH}$, akan mengakibatkan penurunan total fenolik sebanyak $0,111 \%$ untuk bentuk nanokapsul dan 2,825\% untuk bentuk ekstrak. Kondisi ini mencerminkan penurunan total fenolik pada ekstrak lebih cepat jika kondisi $\mathrm{pH}$ dinaikkan satu satuan dibandingkan penurunan yang terjadi pada bentuk nanokapsul.

Mourtzinos et al. (2008) menyatakan bahwa kelopak bunga mengandung senyawa fenolik dan antosianin. Antosianin merupakan sumber antioksidan alami. Pigmen antosianin ini membentuk warna ungu kemerahan pada kelopak rosella. Hal ini dapat dijelaskan berdasarkan perubahan struktur antosianin sebagai fungsi 
dari perubahan $\mathrm{pH}$ (Jackman dan Smith, 1996). Pada kondisi asam $\mathrm{pH}<3$, antosianin berada dalam bentuk flavium, $\mathrm{pH}$ 4-6 bentuk tanpa warna karbinol lebih dominan dalam sistem dan ketika $\mathrm{pH}>7$ bentuk antosianin dalam bentuk quinonoidal. Hal ini sesuai dengan penelitian yang dilakukan Selim et al. (2005)

Ekstrak mengalami penurunan persentase total fenolik terbesar pada $\mathrm{pH}$ tinggi dibandingkan dengan kondisi pada $\mathrm{pH}$ rendah. Hasil tersebut menunjukkan bahwa pada $\mathrm{pH}$ yang semakin meningkat, ekstrak cenderung mengalami kerusakan senyawa fenolik yang terkandung di dalamnya juga mengalami kerusakan. Hal ini kemungkinan disebabkan oleh struktur anthosianin mudah berubah akibat perubahan $\mathrm{pH}$ dan kekuatan ionik larutan.

Pada Gambar 4 terlihat pengaruh $\mathrm{pH}$ terhadap aktivitas antioksidan ekstrak rosella lebih besar dibandingkan pengaruh $\mathrm{pH}$ terhadap aktivitas antioksidan nanokapsul rosella. Berdasarkan kemiringan persamaan regresi yang dihasilkan yaitu untuk ekstrak sebesar 7,634 lebih besar dibandingkan kemiringan persamaan regresi nanoenkapsulan, yaitu 1,307. Hal ini berarti laju penurunan aktivitas antioksidan ekstrak 7,63/1,307 atau sama dengan 5,84 kali laju penurunan aktivitas antioksidan nanokapsul. Menurut Sukhapat et al. (2004) aktivitas antioksidan kelopak bunga rosella dipengaruhi oleh $\mathrm{pH}$ ( $\mathrm{pH}$ 2-7). Semakin meningkat $\mathrm{pH}$, semakin menurun aktivitas antioksidan.
Antioksidan dari kelompok fenolik berfungsi sebagai donor hidrogen yang akan menstabilkan senyawa radikal. Pada $\mathrm{pH}$ yang rendah, densitas ion hidrogen dalam medium meningkat sehingga menekan pelepasan ion hidrogen dari senyawa fenolik. Jadi ion hidrogen dalam medium sudah berfungsi sebagai donor untuk menstabilkan radikal. Hal ini terlihat pada Gambar 3, ekstrak rosella pada $\mathrm{pH}$ 2-4 memiliki aktivitas antioksidan sekitar $70 \%$. Semakin tinggi $\mathrm{pH}$, penurunan aktivitas antioksidan semakin besar pula hingga menjadi $30 \%$ pada $\mathrm{pH} 8$. Hal ini terjadi karena menurut Tensiska et al. (2003) semakin meningkat $\mathrm{pH}$, konsentrasi ion hidrogen dalam medium menurun sehingga mulai terjadi pelepasan ion hidrogen oleh senyawa fenolik (antioksidan). Hal ini berakibat semakin tinggi $\mathrm{pH}$, proteksi antioksidan oleh senyawa fenolik semakin menurun.

\section{Pengaruh variasi suhu dan waktu pemanasan terhadap total fenolik dan aktivitas antioksidan}

Ketahanan terhadap panas merupakan syarat utama yang harus dipenuhi bahan antioksidan jika akan digunakan pada pangan, karena kebanyakan sistem pangan menggunakan temperatur tinggi seperti penggorengan dan pemanggangan. Stabilitas fenolik ekstrak kelopak bunga rosella dilakukan melalui pemanasan ekstrak pada suhu $60,70,80$ selama 15,30 dan 45 menit berdasarkan penghitungan total fenolik sebelum dan sesudah

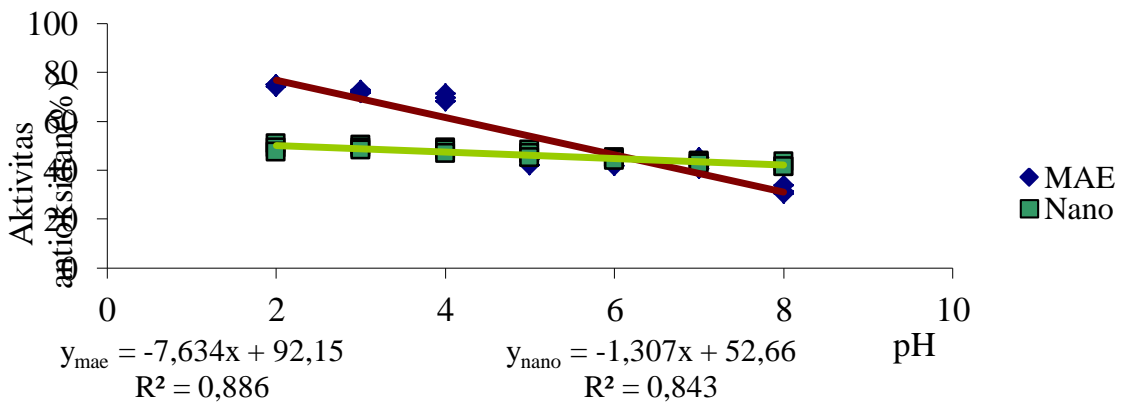

Gambar 4 Pengaruh perubahan $\mathrm{pH}$ terhadap aktivitas antioksidan 


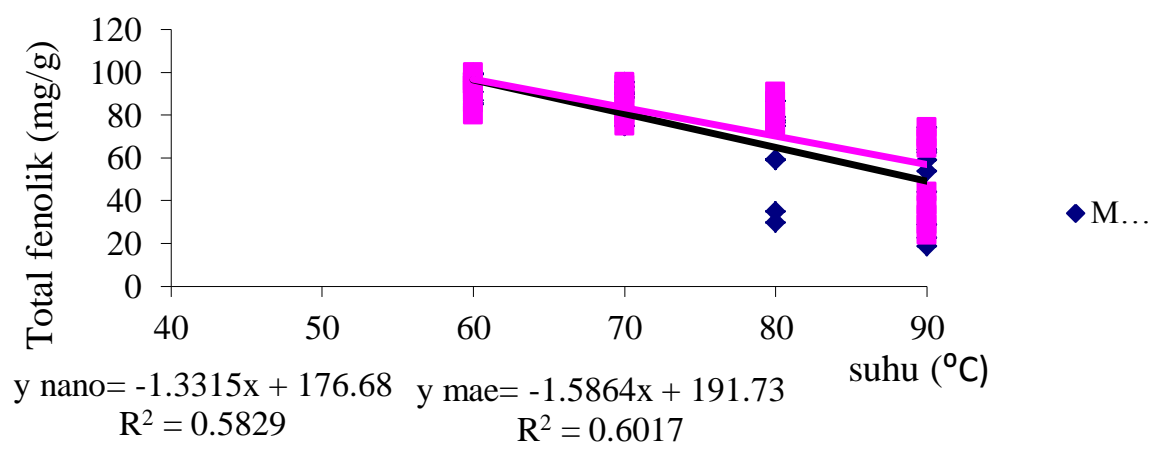

Gambar 5 Pengaruh suhu pemanasan terhadap total fenolik ekstrak dan nanokapsul

Tabel 2 Pengaruh suhu dan waktu pemanasan terhadap retensi fenolik rosella pada pH 2

\begin{tabular}{rrrrrrr}
\hline \multirow{2}{*}{ Suhu $\left({ }^{\circ} \mathrm{C}\right)$} & \multicolumn{3}{c}{ Ekstrak } & \multicolumn{3}{c}{ Nanoenkap } \\
\cline { 2 - 7 } & \multicolumn{3}{c}{ Waktu (menit) } & \multicolumn{3}{c}{ Waktu (menit) } \\
\cline { 2 - 7 } & 15 & 30 & 45 & 15 & 30 & 45 \\
\hline 60 & $99 \%$ & $94 \%$ & $85 \%$ & $97 \%$ & $94 \%$ & $82 \%$ \\
70 & $93 \%$ & $87 \%$ & $83 \%$ & $91 \%$ & $86 \%$ & $76 \%$ \\
80 & $77 \%$ & $58 \%$ & $30 \%$ & $86 \%$ & $80 \%$ & $73 \%$ \\
90 & $63 \%$ & $54 \%$ & $21 \%$ & $69 \%$ & $38 \%$ & $27 \%$ \\
\hline
\end{tabular}

Gambar 5 menunjukan bahwa penurunan laju faktor protektif lebih besar terjadi dalam bentuk ekstrak dibandingkan bentuk nanokapsul. Hal ini terlihat dari kemiringan/slope persamaan regresi untuk sampel berbentuk ekstrak, yaitu 1,5864 dan bentuk nanoenkapsulan sebesar 1,3315. Kondisi ini berarti ekstrak kelopak bunga rosella akan mengalami penurunan kandungan total fenolik sebanyak $1,5864 \%$ untuk setiap kenaikan satu satuan suhu dan lama waktu pemanasan. Bentuk nanokapsul menghasilkan lebih sedikit penurunan kandungan total senyawa fenolik yaitu 1,3315 untuk setiap kenaikan suhu dan waktu pemanasan sebanyak satu satuan.

Tabel 2 memperlihatkan nilai retensi senyawa fenolik untuk pemanasan pada suhu $60^{\circ} \mathrm{C}$ dengan waktu $15,30,45$ menit, baik dalam bentuk ekstrak maupun nanokapsul, berturut-turut 99, 94, dan $85 \%$. Begitu pula untuk suhu $70^{\circ} \mathrm{C}$, nilai retensi untuk fenolik ekstrak masih diatas $80 \%$ hingga 45 menit pemanasan. Hal ini sesuai dengan penelitian yang dilakukan Selim et al. (2004), bahwa antosianin rosella tahan pada suhu tinggi pada waktu pemanasan hingga 45 menit. Salah satu bentuk fenolik dalam rosella adalah antosianin. Setelah dilakukan analisa regresi , ternyata laju penurunan faktor protektif paling besar terjadi pada suhu pemanasan $90^{\circ} \mathrm{C}$ diikuti suhu $80^{\circ} \mathrm{C}$ yang ditunjukkan oleh kemiringan garis yang paling besar.

Gambar 6 mengindikasikan bahwa aktivitas antioksidan dari sampl berbentuk nanokapsul lebih tahan terhadap pemanasan dibanding aktivitasnya dalam bentuk ekstrak. Terlihat dari slope persamaan regresi yang di dapat untuk nanokapsul sebesar 0,3162 lebih kecil dibandingkan slope persamaan regresi ekstrak yang sebesar 1,5561. Penurunan aktivitas antioksidan terhadap perubahan suhu yang semakin tinggi disebabkan oleh aktivitas antioksidan tidak hanya ditentukan oleh jumlah fenolik yang terkandung didalam ekstrak namun juga ditentukan oleh kandungan vitamin $\mathrm{C}$ dan hubungan sinergis antara keduanya. Vitamin $\mathrm{C}$ diketahui tidak stabil pada suhu tinggi. Bentuk nanoenkapsulan terbukti mampu melindungi bahan inti dari kerusakan. 


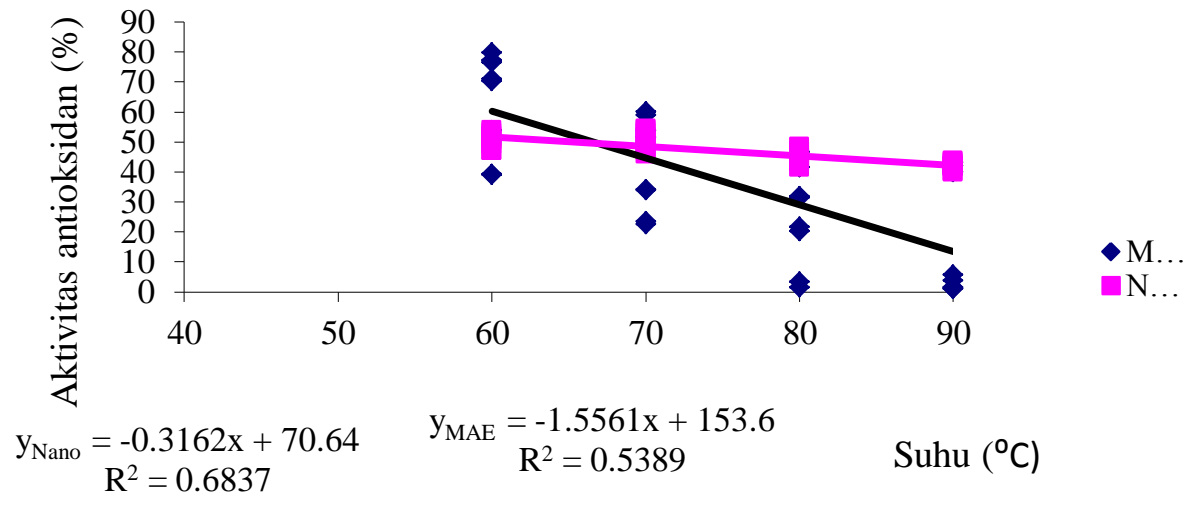

Gambar 6 Pengaruh pemanasan terhadap aktivitas antioksidan ekstrak dan nanokapsul rosella

Konsep umum yang selama ini diketahui, adalah semakin banyak senyawa fenolik dalam sampel, semakin tinggi aktivitas antioksidan yang dihasilkan. Menurut Tsai et al. (2002) aktivitas antioksidan ekstrak rosella memiliki korelasi yang kuat dengan kandungan antosianin. Falade et al. (2005) menyatakan bahwa ekstrak rosella memiliki kandungan vitamin $\mathrm{C}$ yang tinggi. Vitamin $\mathrm{C}$ dikenal sebagai senyawa antioksidan. Hasil ini dimungkinkan karena aktivitas antioksidan tidak hanya disebabkan oleh kandungan fenolik, namun juga dapat disebabkan keberadaan beberapa fitotokimia lain seperti asam askorbat, tokoferol dan pigmen dengan mekanisme sinergis diantaranya turut menentukan aktivitas antioksidan. Aktivitas antioksidan pada sampel berbentuk nanokapsul lebih rendah daripada aktivitasnya dalam bentuk ekstrak, karena untuk berat yang sama kandungan fenolik dan vitamin $\mathrm{C}$ dalam nanokapsul lebih sedikit dibandingkan ekstrak (Gambar 6).

\section{SIMPULAN DAN SARAN}

\section{Simpulan}

Nanokapsul ekstrak rosella memiliki ukuran berkisar 30-40 $\mathrm{nm}$ dengan kandungan total fenolik 4,53 $\pm 0,26 \mathrm{mg} / \mathrm{g}$, antosianin 2,99 $\pm 0,18 \mathrm{mg} / \mathrm{g}$, vitamin C $2,77 \pm 0,04 \mathrm{mg} / \mathrm{g}$ dan kadar air sebesar $5,16+0,03 \%$, dan aktivitas antioksidan $49 \%$. Bentuk nanokapsul lebih tahan terhadap perubahan lingkungan seperti $\mathrm{pH}$, dibandingkan bentuk ekstrak. Hal ini ditunjukkan dengan slope persamaan regresi linier bentuk nano untuk total fenolik dan aktivitas antioksidan berturut-turut: 0,111 dan 1,307; lebih kecil dibandingkan bentuk ekstrak berturut-turut sebagai berikut: 2,825 dan 7,634.

Uji stabilitas senyawa aktif dalam rosela terhadap suhu dan waktu pemanasan dalam penelitian ini menunjukan bahwa bentuk nanokapsul lebih stabil dibanding bentuk ekstrak. Slope persamaan regresi linier bentuk nano untuk total fenolik dan aktivitas antioksidan berturut-turut sebagai berikut: 1,3315 dan 0,3162; lebih kecil dibandingkan bentuk ekstrak, berturut-turut sebagai berikut: 1,5864 dan 0,5389 .

\section{Saran}

Perlu adanya penelitian terapan untuk menjawab kinerja produk nanokapsul yang dihasilkan pada aplikasinya di bidang pangan.

\section{DAFTAR PUSTAKA}

AOAC. 2000. Official methods of analysis of the association of official chemists international, 17thed. The Association of Official Chemists International, Gaithersburg, USA

Al-Hashimi AG. 2012. Antioxidant and antibacterial activities of Hibiscus sabdariffa L extract. African J of Food Sci 6(21):506511

Chew YL, Goh JK, Lim YY. 2009. Assessment of in vitro antioxidant capacity and polyphenolic composition of selected medicinal herbs from Leguminosae family 
in Peninsular Malaysia. Food Chem. 116: 13-18.

Falade OS, Otemuyiwa IO, Oladipo A, Oyedapo OO, Akinpelu BA., Adewusi SRA. 2005. The chemical composition and membrane stability activity of some herbs used in local therapy for anemia. J. Ethnopharmacol, 102:15-22

Fuleki T, Francis FJ. 1968. Quantitative methods for anthocyanins, 1 . Extraction and determination of total anthocyanin in Cranberries, J. Food Sci. 33(1); 72-77

Purbowati, ISM. 2014. Nanoenkapsulasi Ekstrak Kelopak Bunga Rosella(Hibiscus sabdariffa) Hasil Optimasi Ekstraksi Berbantu Gelombang Mikro Sebagai Bahan Antibakteri dan Antioksidan. [Disertasi tidak dipublikasikan. Institut Pertanian Bogor]

Jackman RL dan Smith JL. 1996. Anthocyanins and betalains, in: natural food colourant. GAF Hendry dan JD Houghton (Ed) 2nd ed. Blackie Academic\& professional, Great Britain

Li, Wei, Tao , Keji Tang . 2009. Flavonoids from Mulberry leaves by microwave-assisted extract and anti-fatigue activity. African Journal of Agricultural Research Vol. 4 (9), pp. 898-902

Mourtzinos I, Makris DP, Yannakopoulou K, Kalogeropoulos N, Michali I, Karathsnos VT. 2008. Thermal stability of anthocyanin extract of Hibiscus sabdariffa L.in the presence of $\beta$-Cyclodextrin. $J$. Agric. Food Chem. 56: 1030310310

Naufalin R, Rukmini HS. 2013. Nanoencapsulated of natural antioxidant based on kecombrang (Nicolai speciosa Horan) fruit using cyclodextrin-gelatin as filler ingredient. 13th ASEAN Food Conference, Singapore, 911 September 2013.

Selim KA, Khalil KE, Abdel-bary MS, Abdel Azeim NA. 2005. Extraction, encapsulation and utilization of red pigments from Roselle (Hibiscus sabdariffa) as natural food colorant. Food science and Tech. Dept.

Shahidi F, WasundaraUN. 1995. Oxidative stability of encapsulated seal blubber oil. American Chemical Society: 139151

Sukhapat N, Ungpaiboon S, Itharat A, Puripattanavong J, Pinsuwan S, 2004. Influence of $\mathrm{pH}$ on antioxidant activity of roselle (Hibiscus sbdariffa)extract in aquoeus solution. The 10th World Conggress on Clinical Nutrition in the next decade: Nutraceutical/Functional food: Product Performace in Health, Disease and Safety. Abstract Book organized by PSU, INC and Biotec 30 Nov- 3 Dec, 2004. Phuket, Thailand, p.184

Tensiska, Wijaya, $\mathrm{CH}$, Andarwulan,N. 2003. Aktivitas antioksidan ekstrak buah andaliman (Zanthoxylum acanthopodium DC) dalam beberapa sistem pangan dan kestabilan aktivitasnya terhadap kondisi suhu dan $\mathrm{pH}$. J Teknol dan Ind Pert 14(1):29-39

Tsai PJ, Mcintosh J, Pearse P, Camden B, Jordan TB. 2002. Anthocyanin and antioxidant capacity in Roselle Hibiscus sabdariffa Lextract. Food Res.International 35:351-356.

Wandrey C, Bartkowia A, Harding SE. 2010. Materials for encapsulation. In encapsulation 
technologies for active food ingredients and food processing. Zuidam NJ. and Nedovic VA (Eds.). Springer New York Dordrecht Heidelberg London. pp. $31-100$
Yuliani S, Torley PJ., Bhandari RB. 2006. Mikroenkapsulasi dlimonen untuk perisaan produk ekstrusi. J.Tek.Ind.Pert.17(2),5460 